25 P. H. Holloway and R. L. Long, Jr., IEEE Trans. Parts Hybrids Packag., 1975, PHP11, 83-88

26 N. T. Panousis and H. B. Bonham in 'Proc. 11th Annu. Reliab. Phys. Conf.', Las Vegas, 1973, pp.; 21-25

27 D. R. Johnson, Sandia Laboratories Rep. SC-DR-71-0539 Dec. $1971^{\star}$

28 P. H. Holloway, 7. Vac. Sci. Technol., 1975, 12, 1418-1422

29 I. R. Rairden, C. A. Neugebauer and R. A. Sigsbee, Metall. Trans., 1971, 2A, 719-22

30 G. L. Schnable and R. S. Keen, Tech. Rep. No. RADC TR-66-165, 1966*

31 R. E. Thomas and G. A. Haas, f. Appl. Phys., 1972, 43, 4900-4907

32 J. K. Hirvonen, W. H. Weisenberger, J. E. Westmoreland and R. A. Meussner, Appl. Phys. Lett., 1972, 21, 37-39

33 P. S. Kendrick, Nature, 1968, 217, 1249-1250

34 A. L. Pranatis, 'Diffusion Studies for Microcircuit Metallizations', Report of NRL. Progress, Naval Research Laboratory, Washington, D.C., May 1971, p. 21

35 G. C. Nelson and P. H. Holloway in 'Surface Analysis Techniques for Metallurgical Applications', ASTM STP 596, American Society for Testing and Materials, Philadelphia PA., 1976 , pp. 68.78

36 P. H. Holloway, D. E. Amos and G. C. Nelson, F. Appl. Phys., $1976,47,3769-3775$
37 R. E. Hampy, F. G. Yost and F. P. Ganyard, 7. Vac. Sci. Technol. $1979, \mathbf{1 6}, 25-30$

38 P. H. Holloway and G. C. Nelson, Thin Solid Films, 1976, 35, L13-L16

39 D. M. Mattox and R. R. Sowell in 'Proc. 7th Int. Vac. Congr \& 3rd Int. Conf. Solid Surf.', Vienna, 1977, pp. 2659-2662

40 P. H. Holloway and D. W. Bushmire in 'Proc. 12th Int. Symp. Reliab. Phys.', Las Vegas, 1974, pp. 180-186

41 D. W. Bushmire and P. H. Holloway, in 'Proc. Int. Microelectron. Symp.', Vancouver, B.C., Int. Soc. for Hybrid Microelectron., P.O. Box 3255, Montgomery, AL. 36109 , U.S.A., 1975, pp. $402-408$

$42 \mathrm{~J}$. L. Jellison in 'Proc. 25th Electron. Components Conf.', Washington, D.C., 1975, p. 271-277

43 F. G. Yost, Gold Bull., 1977, 10, (4), 94-100

44 F. G. Yost, F. Electron. Mater., 1974, 3, 353-369

45 H. C. Olson and G. L. Knauss, Sandia Laboratories Rep. SLA-73-1084, Oct. 1974^

46 D. W. Palmer and F. P. Ganyard, IEEE Trans. Components Hybrids Manuf. Technol, 1978, CHMT1, 219-222

47 E. Philofsky, Solid State Electron., 1970, 13, 1391-1399

*Available from National Technical Information Service, U.S. Department of Commerce, 5825 Port Royal Road, P.O. Box 1153 Springfield, VA. 22151, U.S.A

\title{
Automatic Selective Brush Plating of Gold
}

\section{APPLICATION TO TRANSISTOR AND INTEGRATED CIRCUIT HEADERS}

The selective gold plating of intricately shaped articles presents difficulties and for many years transistor headers were barrel-plated despite the fact that gold was needed only on those areas where wire or wafer bonding was required. The restriction of gold plating essentially to these areas is made possible, however, using equipment which has been developed by the Auric Corporation of Newark, NJ., (U.S.Patents 3,951,772 and 4,048,043).

In this, the headers are carried on a stainless steel band with the surface to be plated at a fixed height above a moving felt belt which is kept impregnated with electrolyte from the gold plating bath through which it passes. A copper brush serves as the cathode and platinum mesh as the anode. A proprietary electrolyte (Auric 609), which is a neutral gold bath containing citrates and phosphates, or its equivalent, is recommended for use with the equipment, which can be adapted to plate most types of headers. These are fed into the machine after cleaning by normal procedures and drying, and after plating are unloaded automatically into a container of distilled water. They are then rinsed and dried.

Depending on the design of the units and the gold thickness desired, the equipment will plate 8000 to 14000 headers per hour at an energy consumption which is a fraction of that in barrel-plating. The resulting gold coatings have been found to give higher bonding yields than those produced by barrel-plating, and the equipment is approved for use by six major semiconductor manufacturers.

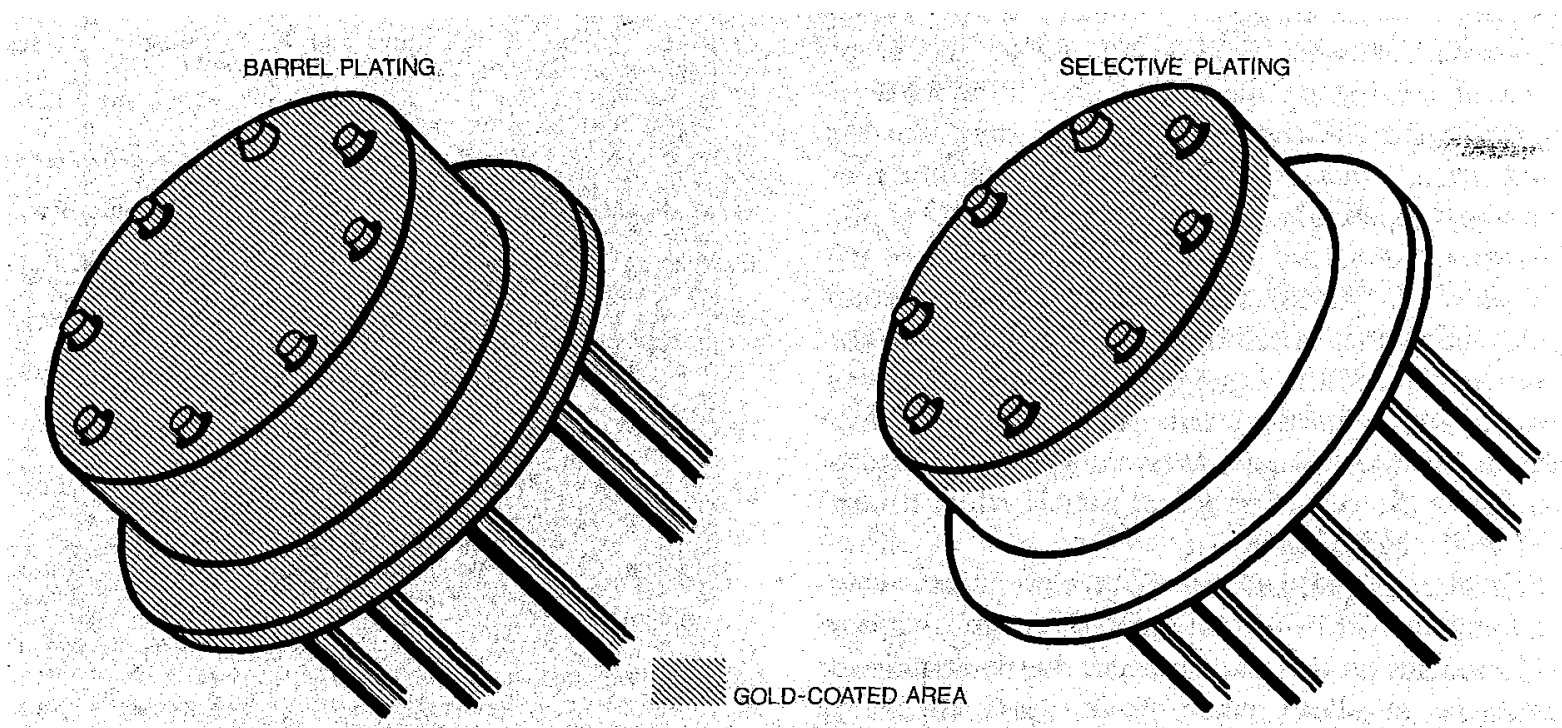

Schematic representation of the results of barrel-plating and selective brush plating transistor headers with gold 